\title{
The adherence of the multi-professional team to preventive measures of ventilator-
}

\section{associated pneumonia}

\author{
A adesão da equipe multiprofissional às medidas preventivas dla pneumonia associadla à ventilação \\ mecânica
}

La adhesión del equipo multiprofesional a las medidas preventivas de la neumonía asociada al ventilador

Received: 10/08/2021 | Reviewed: 10/14/2021 | Accept: 10/14/2021| Published: 10/17/2021

Angela Maria Chastay
ORCID: https://orcid.org/0000-0003-0337-8829
Universidade Estadual de Ponta Grossa, Brazil
E-mail: angelamcuepg @ gmail.com
Janaini Brunoski
ORCID: https://orcid.org/0000-0002-4541-5926
Universidade Estadual de Ponta Grossa, Brazil
E-mail: janainibuepg @ gmail.com
Arthur Garani Narciso
ORCID: https://orcid.org/0000-0002-3910-4435
Universidade Estadual de Ponta Grossa, Brazil
E-mail: arthurnarcisoedu @ gmail.com
Elder Dalazoana Filho
ORCID: https://orcid.org/0000-0002-9263-0565
Universidade Estadual de Ponta Grossa, Brazil
E-mail: eldinhodalazoana @ outlook.com
João Pedro Gambetta Polay
ORCID: https://orcid.org/0000-0003-0170-1469
Universidade Estadual de Ponta Grossa, Brazil
E-mail: polayjp@gmail.com
Guilherme Arcaro

\begin{abstract}
Objective: The main purpose of this paper was to evaluate the incidence of Ventilator-Associated Pneumonia (VAP) in an Intensive Care Unit (ICU) and the adherence of the bundles by healthcare professionals. Methodology: This study was prospective, observational, and quantitative, performed in an ICU located in Ponta Grossa (Paraná, Brazil) gathering data from December 2018 to February 2019 through medical records and bedside observations. Results: This study included 56 patients, of whom 3 acquired VAP. The multi-professional team performed several procedures that met the prevention bundles in that UCI, writing them down in medical records, but some of them were not being applied in practice or were not performed properly, exposing divergences between annotations and bedside observations. Conclusion: It is noted that bundles are effective in preventing VAP, reduces risks of HAI and, consequently, deaths. However, there is a need to guide the applicability and registration by the multidisciplinary team, optimizing the adherence of these measures, in order to improve the quality of health of patients and reducing costs and the length of stay in the ICU related to VAP.
\end{abstract}

Keywords: Intensive Care Unit; Health care-related infections; Pneumonia; Mechanical pulmonary ventilation.

\section{Resumo}

Objetivo: O objetivo principal deste artigo foi avaliar a incidência de pneumonia associada à ventilação pulmonar mecânica (PAV) em uma Unidade de Terapia Intensiva (UTI) e a adesão dos bundles por profissionais de saúde. Métodos: O estudo foi prospectivo, observacional e quantitativo, realizado em uma UTI localizada em Ponta Grossa (PR), com coleta de dados no período de dezembro de 2018 a fevereiro de 2019 por meio de prontuários e observações à beira do leito. Resultados: Este estudo incluiu 56 pacientes, dos quais 3 adquiriram PAV. A equipe 
multiprofissional realizou diversos procedimentos que atendiam aos bundles de prevenção daquela UCI, anotando-os nos prontuários, mas alguns deles não estavam sendo aplicados na prática ou não foram realizados de forma adequada, expondo divergências entre anotações e observações à beira do leito. Conclusão: Salienta-se que os bundles são eficazes na prevenção da PAV, reduzem os riscos de IRAS e, consequentemente, óbitos. No entanto, há a necessidade de orientar a aplicabilidade e o registro pela equipe multiprofissional, otimizando a adesão dessas medidas, a fim de melhorar a qualidade de saúde dos pacientes e reduzir os custos e o tempo de permanência na UTI relacionados à PAV.

Palavras-chave: Unidade de Tratamento Intensivo; Infecções relacionadas a cuidados de saúde; Pneumonia; Ventilação pulmonar mecânica.

\section{Resumen}

Objetivo: El objetivo principal de este artículo fue evaluar la incidencia de neumonía associada a ventilación pulmonar mecânica (NAV) en una Unidad de Terapia Intensiva (UCI) y la adherencia de los paquetes por parte de los profesionales de la salud. Metodologia: El estudio fue prospectivo, observacional y cuantitativo, realizado en una UCI ubicada en Ponta Grossa (PR), con recolección de datos desde diciembre de 2018 a febrero de 2019 a través de historias clínicas y observaciones de cabecera. Resultados: Este estudio incluyó a 56 pacientes, 3 de los cuales adquirieron NAV. El equipo multidisciplinario realizó varios procedimientos que cumplieron con los haces de prevención de esa UCI, registrándolos en la historia clínica, pero algunos de ellos no se estaban aplicando en la práctica o no se realizaban adecuadamente, exponiendo diferencias entre notas y observaciones a pie de cama. Conclusíon: Cabe señalar que los paquetes son eficaces en la prevención de NAV, reduciendo el riesgo de HAI y, en consecuencia, la muerte. Sin embargo, es necesario orientar la aplicabilidad y registro por parte del equipo multidisciplinar, optimizando la adherencia a estas medidas, con el fin de mejorar la calidad de salud de los pacientes y reducir los costes y la estancia en UCI relacionados con NAV.

Palabras clave: Unidad de Cuidados Intensivos; Infecciones relacionadas con la atención médica; Neumonía; Ventilación pulmonar mecánica.

\section{Introduction}

An Intensive Care Unit (ICU) is a highly specialized care environment, where patients with systemic instability an imminent risk of death are referred. Once that sector is susceptible to the occurrence of adverse events and incidents, the patient needs continuous care, with trained professionals to attend several highly complex situations. Patients referred to the ICU are usually submitted to various procedures, which can be invasive, such as mechanical ventilation (MV), which is one of the most used measures in patients undergoing intensive care (Oliveira \& Nunes, 2015; Silva et al., 2017).

All patients admitted to the ICU have a higher risk of developing Health Care-Related Infections (HAI), which are infections that affect the patient, whether in hospital institutions, in outpatient or home care that may be associated with some type of assistance procedure performed by the multi-professional team (Cardoso, 2015). The HAIs cause alarming risks to the patient's health. Their prevention and control are very important and should involve measures and actions by professionals that result in improving the quality of health care (Rodrigues et al., 2016).

Among the HAIs, pneumonia associated with mechanical ventilation (VAP) can be mentioned, which is the most important and most common HAI. According to Maran et al. (2019), pneumonia is responsible for 15\% of HAIs and approximately $25 \%$ of all infections acquired in ICUs. VAP is defined as an infection that occurs after 48 hours of mechanical ventilation or that is diagnosed within 72 hours after extubation, that is, it can be early or late-onset (Silva et al., 2017). According to other studies, VAP has a higher rate ranging from $9 \%$ to $67 \%$ of patients who are submitted to the use of in vasive mechanical ventilation in the ICUs (Melo et al., 2019).

According to this information, it is important to survey the main risk factors for VAP, which we can divide into three categories; conditions that can facilitate broncho aspiration; factors that increase gastrointestinal tract colonization; and factors of the individual, such as age, immunosuppression, and severity at admission (Leite \& Silva, 2018). In order to contribute to the reduction of the nosocomial infection rate in health care such as VAP, the Institute for Healthcare Improvement (IHI) developed bundles, which constitute the set of measures that applied together can prevent certain infections (Oliveira \& Nunes, 2015). Currently, this set of measures has been widely used, especially in the prevention of VAP, but applying these measures 
in day-to-day care practice becomes a great challenge because, in order to obtain the expected result, it is necessary that the entire team be motivated and actually perform the measurement correctly as it is in the protocol (Cardoso, 2015).

In order to adequately provide health services to patients in the ICU due to the rates of this adverse event, it is essential that professionals acquire necessary and decisive knowledge related to the care provided to VAP (Silva et al., 2014). Based on this statement, it was studied what preventive care measures for VAP are really harmful to professionals and whether it is a technique verified in the checklist that is actually being performed correctly. In the context of the COVID-19 pandemic, the collective and consistent application of bundles can improve the prognosis of hospitalized patients. However, because the published studies are very recent, the real outcome still requires more research for concrete results (Smith et al., 2018).

Therefore, this study aims to assess the profile of patients using MV; to assess the adherence of the multidisciplinary team to bundles for preventing pneumonia associated with mechanical ventilation in the ICU; to identify what care is provided by professionals in the prevention of VAP on a daily basis.

\section{Methodology}

This is prospective quantitative and observational research. The study setting was an adult ICU at the Wallace Thadeu de Mello e Silva Regional University Hospital in Ponta Grossa - Paraná. This ICU consists of 10 beds with exclusive care by SUS.

During the period from December 2018 to February 2019, data were collected through direct observation at the bedside of patients admitted to the ICU of the Regional University Hospital Wallace Thadeu de Mello e Silva in Ponta Grossa Paraná, monitoring and analyzing the multidisciplinary team while providing care to patients, to verify which measures from the package were being provided to patients who met the inclusion criteria. Thus, the patients were observed during and moments after the procedures were carried out. Concomitant to the prospective evaluation at the bedside, the data recorded in the medical records of these same patients were observed, in order to relate the data recorded in the medical records by the multidisciplinary team, and the data actually performed in the patients under careful observation of the application of the bundles in the ICU.

The inclusion criteria in the research were: patients hospitalized for more than 24 hours in the ICU and who used health devices in mechanical ventilation, regardless of developing infection or not. Exclusion criteria were: death within 24 hours of admission to the ICU and patients with restricted pack use, excluding those who could not keep the Headboard elevated between $30^{\circ}$ and $45^{\circ}$, who could not interrupt the sedation, could not perform oral hygiene with chlorhexidine or could not be removed from the bed.

The evaluated data were collected by accessing the records of the following data from the patient's medical record:

1. Sex;

2. $\quad$ Birth and age;

3. Infections;

4. Diagnosis;

5. Hospitalization date;

6. Start and end of the use of an orotracheal tube (TOT) / mechanical ventilation (MV) date;

7. Outcome (discharge or death).

For data collection in relation to the preventive measures of VAP, a checklist material was used, where the information was the bundles' package:

1. Headboard elevated between $30^{\circ}$ and $45^{\circ}$; 
2. Interruption of sedation;

3. Oral hygiene with chlorhexidine;

4. Aspiration of the upper airways;

5. Cuff pressure between 20 and $25 \mathrm{mmH}_{2} \mathrm{O}$;

6. Humidifying filter within the expiration date;

7. The positioning of the appropriate TOT;

8. Removal of the patient from the bed.

The data obtained were stored in a Microsoft Office Excel spreadsheet and subsequently analyzed using the Statistical Package for the Social Science (SPSS) program. In the first stage, a descriptive statistical analysis of all variables was performed. For the comparison between the two evaluation moments, McNemar's nonparametric test was applied. This test is applied when the objective is to analyze two paired, related samples, as in the case of before and after an intervention. Thus, it is sought with these tests to verify the significance of the changes from the retrospective to the prospective moment, considering a significance level of $5 \%$.

This study was approved by the Ethics Committee in Research in Human Beings of the Science Sector of State University of Ponta Grossa, under the CAAE registration number 01599618.6.0000.0105 and opinion of COEP number 2.991.245.

\section{Results and Discussion}

During the study period, there were 155 patients admitted to an ICU, as shown in Table 1. In this background, regarding patients undergoing invasive mechanical ventilation, there were a total of 56 patients: 16 (28,57\%) women and 40 $(71,43 \%)$ men. The mean age of the patients studied was 60,46. Regarding the outcome, of the 56 patients, $21(37,50 \%)$ were discharged from the hospital, and $35(62,50 \%)$ died. Regarding the development of infections, $39(69,64 \%)$ patients developed some infection, and $17(30,36 \%)$ did not. Among the total of 41 infections, there were 3 cases of VAP, 28 of Pneumonia (PNM), 5 Urinary Tract Infection (UTI), and 5 Abdominal infections. Therefore, the same patient developed two infections, as shown in Table 2.

As for the patients' diagnoses, they were divided into categories, namely: Respiratory Disorders (9), Cardiological Disorders (11), Neurological Disorders (17), Surgical Procedures (7), and Other disorders (12).

Table 3 describes the data related to the application of the VAP prevention bundles, where a total of 324 observations were made, which are expressed in observation data at the bedside (prospective study) and the observation of the checklist notes (retrospective).

As for the positioning of the OTT and the removal of the patient from the bed, they were evaluated only in the prospective study, as they are not part of the institution's bundle checklist, and cannot be evaluated in the retrospective, as shown in Table 3. 
Table 1. General data from the ICU from December 2018 to February 2019.

\begin{tabular}{lll}
\hline Variables & $\mathbf{n}$ & \% \\
\hline Total admitted patients & 155 & 100 \\
MV use / patient & 56 & 36,12 \\
Sex & & \\
Male & 92 & 59,35 \\
Female & 63 & 40,68 \\
Outcome & & \\
High & 116 & 74,84 \\
death & 39 & 25,16 \\
\hline
\end{tabular}

Source: Own elaboration.

Table 2. General data on MV patients from December 2018 to February 2019.

\begin{tabular}{lll}
\hline Variables & n & \% \\
\hline Sex & 40 & 71,43 \\
Male & 16 & 28,57 \\
Female & & \\
Outcome & 21 & 37,50 \\
High & 35 & 62,50 \\
Death & & \\
Infection & 39 & 69,64 \\
Yes & 17 & 30,36 \\
No & & \\
Infections & 28 & 68,29 \\
PNM & 3 & 7,32 \\
VAP & 5 & 12,20 \\
UTI & 5 & 12,20 \\
Abdominal & 41 & 100 \\
Total infections & & \\
\hline & & \\
\hline & & \\
\hline
\end{tabular}

Source: Own elaboration. 
Table 3. Prospective and retrospective data on the application of the VAP prevention bundles.

\begin{tabular}{|c|c|c|c|}
\hline Prevention measures & Prospective & Retrospective & p Value \\
\hline \multicolumn{4}{|l|}{ Raised headboard $30-45^{\circ}$} \\
\hline Yes & 219 & 324 & \\
\hline No & 105 & 0 & \\
\hline Daily interruption of sedation & & & $<0,05$ \\
\hline Yes & 183 & 139 & \\
\hline No & 141 & 185 & \\
\hline \multicolumn{4}{|l|}{ Oral hygiene with chlorhexidine } \\
\hline Yes & 322 & 324 & \\
\hline No & 2 & 0 & \\
\hline Upper airway aspiration & & & 0,065 \\
\hline Yes & 315 & 322 & \\
\hline No & 9 & 2 & \\
\hline Cuff pressure $20-25 \mathrm{mmH}_{2} \mathrm{O}$ & & & $<0,05$ \\
\hline Yes & 196 & 322 & \\
\hline No & 128 & 2 & \\
\hline \multicolumn{4}{|c|}{ Humidifier filter within the expiration date } \\
\hline Yes & 277 & 324 & \\
\hline No & 47 & 0 & \\
\hline \multicolumn{4}{|l|}{ TOT positioning } \\
\hline Yes & 239 & $\mathrm{X}$ & \\
\hline No & 85 & $\mathrm{X}$ & \\
\hline Percentage achievement & $73,76 \%$ & & \\
\hline \multicolumn{4}{|l|}{ Patient removal from the bed } \\
\hline Yes & 6 & $\mathrm{X}$ & \\
\hline No & 318 & $\mathrm{X}$ & \\
\hline Percentage achievement & $1,85 \%$ & & \\
\hline Total & 324 & & \\
\hline
\end{tabular}

Source: Own elaboration.

It was observed that the ICU had 155 admitted patients, 56 of whom used MV. Regarding the admitted patients, there was a rate of 39 deaths, 35 of them, of patients with MV. Ribeiro et al. (2018) point out that more than 50\% of patients undergoing MV die, and the percentage of this study is $62,5 \%$.

It can be seen that the patients in the present study are mostly male (71\%), with an average age of 60,46 years, in agreement with other studies, which show similar data regarding age. Bezerra (2012) points out that the elderly (over 60 years old) are the main patients in ICUs, being able to occupy more than $50 \%$ of the vacancies in this hospital sector. Regarding the sex of the patients, the study by Silva (2011) points out the male predominance, in line with the data obtained by our study.

It is widely known that prolonged ICU stay increases the patient's chance of death. therefore, in relation to the outcome, $62,5 \%$ of deaths were registered, similar to the study by Ribeiro et al. (2018), where $51,1 \%$ of the patients on mechanical ventilation analyzed died.[9] In the study by Chouhdari et al. (2018), $40 \%$ of patients died. Another relevant fact 
was that $69,64 \%$ of patients with MV had some type of infection. Only 7,3\% were pneumonia associated with mechanical ventilation. Silva et al. (2017) show that the incidence of VAP in ICU patients can vary from $9 \%$ to $67 \%$, in addition to increasing the mortality rate, which can be higher than $50 \%$ of cases. In the study by Chouhdari et al. (2018), $8 \%$ of patients had VAP. Therefore, there is a tendency towards adequate VAP prevention practices, but with the possibility of improvement for adequate prevention.

Regarding the diagnosis of hospitalization among patients admitted to the ICU who used MV, most were neurological disorders (17) followed by 11 cardiac disorders, 9 of them had respiratory disorders, 7 were from surgical procedures and 12 refer to other disorders, similar to the results obtained by Bezerra (2012) where cardiovascular and respiratory disorders were predominant.

It is agreed that the application of preventive actions in patients with mechanical ventilation is relevant to its recovery. Maranet al. (2019) states that bundles are used by the multidisciplinary team with the intention of considerably improving health care for these patients. For this, it is essential that the responsible nurses know how to act assertively about the necessary care for the prevention of diseases associated with MV. Aloush (2018) agrees with the statement, and in his study found a significant improvement in occurrences of VAP when using bundles.[12] In this data collection, 56 patients and 324 moments of application of preventive measures were observed, unlike the study by Bork, Gaspar, and Reche (2014), which analyzed 33 patients and 1522 actions.

According to Table 3, it can be observed that there was a divergence in what was being observed for what was being noted in the medical record. Regarding the elevated headboard, it can be noticed that in the observation at the bedside, of the 324 occurrences, only 219 had the headboard elevated in the correct degree and 105 were in the wrong position, and when seeing what the team was checking, it was placed that, at all times, the headboard was elevated within the correct value.

As for the interruption of sedation, in the retrospective moment it was observed that, in 139 of the times, sedation was being interrupted. However, when observing the bedside, 183 interruptions were being made. In other words, the check was also being carried out without complying with the assistance provided. Regarding the performance of oral hygiene with chlorhexidine, there was a variation in two cases between the prospective (322) and the retrospective (324) data.

As for upper airway aspiration, in 315 observations, aspiration was performed and in just 9 moments it was not performed, with a low level of disagreement between the prospective and the retrospective. in addition, no statistically significant difference was noted between the analysis periods $(\mathrm{p}=0.065)$.

Regarding the cuff pressure between $20-25 \mathrm{mmH} 2 \mathrm{O}$, it was the topic that showed the greatest divergence, since in the observation at the bedside, only 196 were correct, and the team was listed that 322 observations were correct, displaying a quantitative difference between values $(\mathrm{p}<0.05)$. In other words, the team responsible for the check considered that the cuff pressure was correct, but there are differences regarding our analysis.

As for the validity of the humidifier filter, again we found divergences between the team's conference and our observation. The team found that, in all cases, the filter was within its validity period, however, in the observation at the edge of the bed, only 277 were correct.

As for the elevation of the head, we obtained 219 occurrences, resulting in 70,95\%, similar to the research by Bork, Gaspar, and Reche (2014), where patients who had the head elevated did not develop VAP. Atashi et al. (2018) also agree that the correct elevation of the headland favors the improvement of VAP occurrences. The author also argues that the team of nurses, even without extensive knowledge about bundles, knows the benefits of correct elevation. In the study by Hereu and Marañón (2017), the head elevation was a practice with little adherence, despite the knowledge of the importance of its realization. 
Regarding the daily interruption of sedation, we noticed $56,48 \%$ of occurrences, while the study by Bork, Gaspar, and Reche (2014), noticed 76,94\%. In addition, a statistical difference was noted between the observed values ( $p<0.05$ ). It is worth noting that this measure is recommended and favorable for the cough reflex and the possible premature removal of the orotracheal tube. Shahabiet al. (2016) comments that the daily interruption of sedation is important for the prevention of VAP, but emphasizes that this measure must occur daily. In their studies, the group of patients who had this practice applied had fewer occurrences of VAP than the control group.

Regarding oral hygiene with chlorhexidine and aspiration of the upper airways, we observed 99,38\% of positive occurrences for that and $97,22 \%$ for this, which contributes to the prevention of infections. Bork, Gaspar and Reche (2014), noted that there was a low adherence to these methods, and the risk increased for patients who did not have these practices in effect, going against our study, where adherence was quite significant. Cornistein et al. (2018) argue that there is much controversy regarding the use of oral hygiene to prevent VAP, however, their study reveals that patients who had this practice applied did not present VAP, but that oral hygiene is not specifically proven to directly influence. In the study by Güler and Türk (2018), the rate of development of VAP in patients that this practice was applied was $0,12 \%$ lower than in patients who did not have hygiene performed.

The importance of the correct cuff pressure in MV patients is emphasized since the incorrect pressure can result in greater contact with bacteria and a possible compromise regarding the microcirculation of the tracheal mucosa. From that, we found that $60,49 \%$ of the patients had a pressure between 20 and $25 \mathrm{~mm} \mathrm{H}_{2} \mathrm{O}$, while in the study by Bork, Gaspar, and Reche (2014) $69,17 \%$ had the same result.

According to Bork, Gaspar and Reche (2014), there is no consensus in the literature regarding the humidifier filter within the expiration date (every 48 hours or after 72 hours), when it comes to preventing infections. Those authors identified an adherence of $90,99 \%$ on this strategy, while our study is compared, with $85,49 \%$ of occurrences. Larrow and Heartt (2016) argue that the use of the humidifier filter within the expiration date may be the key to the prevention of VAP.

As for the positioning of TOT and the removal of the patient from the bed, Bork, Gaspar and Reche (2014) did not analyze these data. However, our study showed adherence of 73,76\% and 1,85\%, respectively. Larrow and Heartt (2016) confirm that the premature removal of the patient from the bed decreases the risk of incidence of VAP. Li et al. (2018) included removing the patient from the bed in his study of implementing a bundle checklist, which remained to obtain positive results.

During our study, 7,3\% of patients had VAP. As previously mentioned, Silva et al. (2017) show that the incidence of VAP in ICU patients can vary from $9 \%$ to $67 \%$. Therefore, our study presented results below the estimated average, which leads us to believe that the application of bundles was efficient in preventing infection. The result of the study by Aloush (2018) is similar to ours, with a 3,1\% incidence of VAP. However, it is noted that there are still differences in relation to the information provided in the checklist with what is actually carried out.

\section{Final Considerations}

In the course of this study, it can be seen that the applicability of VAP prevention bundles are very important, as they are simple and easy to perform practices that prevent not only pneumonia associated with mechanical ventilation but reduce the risk of death of the patient. It can also be seen that it is not the use of a procedure, but that the joint use of these practices presents better results, reducing costs and even reducing the time of this patient in the ICU.

In addition, it is important to emphasize that nurses' work must be continuous and frequent since there is a real need to intensify preventive actions. For this reason, the ICU team is constantly updated and guided by these data, aiming at improving the results and a better quality of health for patients who present themselves in this situation. It is necessary to raise the 
awareness of the team responsible for the correct application of bundles, so that the data in the checklist does not become just numbers, but acts themselves, and performed to improve the patient's health.

\section{References}

Aloush, S. M. (2017). Nurses' implementation of ventilator-associated pneumonia prevention guidelines: an observational study in Jordan. British Ass. CriticalCare Nurses. 23(3):147-151.

Atashi, V., Yousefi, H., Mahjobipoor, H., \& Yazdannik, A. (2018). The barriers to the prevention of ventilator-associated pneumonia from the perspective of critical care nurses: A qualitative descriptive study. Wiley Journal Clin. Nursing. 27(5-6):1161-1170.

Bezerra, E. L., Lima, A. I. F., Nóbrega, A. R. R., Barroso, D. N., Donadi, H. A., Santos, J. G. S., et al. (2012). Prevalência de Pneumonia em pacientes de uma unidade de terapia intensiva de um hospital-escola de Fortaleza-CE. Rev. Bras. Promo. Saúde. 25(2):20-24.

Bork, L. C. A., Gaspar, M. D. R., \& Reche, P. M. (2014). Adesão às medidas preventivas de pneumonia associada à ventilação mecânica. Rev.Epid. Control. Infecção. 5(1):12-16.

Cardoso, V. B. (2015). Entendimento dos enfermeiros intensivistas sobre as formas de prevenção de pneumonia associada à ventilação mecânica invasiva: uma revisão da literatura. Rev Eletrôn. Atualiza Saúde. 1(1):25-34.

Chouhdari, A., Shokouhi, S., Bashar, F. R., Azimi, A. V., Shojaei, S. P., Fathi, M., et al. (2018). Is a Low Incidence Rate of Ventilation Associated Pneumonia Associated with Lower Mortality? a Descriptive Longitudinal Study in Iran. Tanaffos, 17(2):110-116.

Cornistein, W., Colque, A. M., Staneloni, M. I., Lloria, M. M., Lares, M., González, A. L., et al. (2018). Neumonía asociada a ventilación mecánica. Actualización y recomendaciones inter-sociedades, Sociedad Argentina de Infectología - Sociedad Argentina de Terapia Intensiva. Medicina. 78(2):99-106.

Güler, E. K., \& Türk, G. (2018). Oral Chlorhexidine Against Ventilator- Associated Pneumonia and Microbial Colonization in Intensive Care Patients. Western Journ. Nurs. Resear. 41(6):901-919.

Hereu, L. M., \& Marañón, A. A. (2017). Tiempo de elevacióndelcabezal de la cama del paciente conventilaciónmecánica y factores relacionados. Enferm Intensiva. 28(4):169-177.

Khan, R., Al-Dorzi, H., Al-Attas, K., Ahmed, F. W., Marini, A. M., Mundekkadan, S., et al. (2016). The impact of implementing multifaceted interventions on the prevention of ventilator-associated pneumonia. American Journal of Infection Control. 44(3):320-6.

Larrow, V., \& Heartt, K. (2016). Prevention of Ventilator-Associated Pneumonia in the Intensive Care Unit: Beyond the Basics. Journ. Neuroscien. Nursing. $48(3): 160-5$.

Leite, R. F., \& Silva, B. M. (2018). Perfil epidemiológico e análise clínica de pacientes com pneumonia associada à ventilação mecânica em um hospital de ensino. Rev Ciências em Saúde. 8(3):14-8.

Li, L., et al. (2018). Development, validation and application of a ventilator-associated pneumonia prevention checklist in a single cardiac surgery center. Intensive \& Critical Care Nursing 49:58-64.

Maran, E., Spigolon, D. N., Melo, W. A., Barreto, M. S., Tostes, M. F. P., \& Teston, E. F. (2019). Prevenção da pneumonia associada à ventilação mecânica sob a ótica de acadêmicos de enfermagem. Rev. FunCareOnline. 11(1):118-23.

Melo, M. M., Santiago, L. M. M., Nogueira, D. L., \& Vasconcelos, M. F. (2019). Pneumonia associada à Ventilação Mecânica: Conhecimento dos Profissionais de Saúde Acerca da Prevenção e Medidas Educativas. RevFundCare Online. 11(2):377-382.

Oliveira, M. L. L., \& Nunes, R. D. (2015). Bundles de prevenção da pneumonia associada à ventilação mecânica em unidade de terapia intensiva. Revista Amazônica Science\&Health. 3(2):36-43.

Ribeiro, C. L., Barbosa, I. V., Silva, R. S. M., Cestari, V. R. F., Penaforte, K. L., Custódio, I. L. (2018). Clinical characterization of patients under mechanical ventilation in a intensive therapy unit. Rev Fund Care Online. 10(2):496-502.

Rodrigues. N. A., Fragoso, L. V. C., Beserra, F. M., \& Ramos, I. C. (2016). Determining impacts and factors in ventilator-associated pneumonia bundle. Rev Bras Enferm. 69(6):1045-51.

Shahabi, M, Youselfi, H, Yazdannik, A. R, \& Alikiaii, B. (2016). The effect of daily sedation interruption protocol on early incidence of ventilator-associated pneumonia among patients hospitalized in critical care units receiving mechanical ventilation. IranianJourn. Nurs. Midwif. Resear. $21(5): 541-546$.

Silva, R. M., Silvestre, M. O., Zocche, T. L., \& Sakae, T. M. (2011). Pneumonia associada à ventilação mecânica: fatores de risco. Ver Bras CLin Med. 9(1):510 .

Silva, S. G., Salles, R. K., Nascimento, E. R. P., Bertoncello, K. C. G., \& Cavalcanti, C. D. A. K. (2014). Pneumonia associada à ventilação mecânica: discursos de profissionais acerca da prevenção. Esc Anna Nery. 18(2):290-295.

Silva, T. F., Souza, G. N., Souza, S. S., Bitencourt, J. V. V., Madureira, V. F., \& Luzardo, A. R. (2017). Incidência de pneumonia associada à ventilação mecânica em uma Unidade de Terapia Intensiva. Rev.FundCareOnline. 9(4):1121-1125.

Smith, V., Declan, D., Nichol, A., \& Roche, D. (2020). Care bundles for improving outcomes in patients with COVID-19 or related conditions in intensive care - a rapid scoping review. Cochrane Database Syst Rev. 12(12): CD013819. 